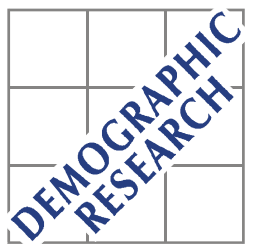

Demographic Research a free, expedited, online journal of peer-reviewed research and commentary in the population sciences published by the Max Planck Institute for Demographic Research Konrad-Zuse Str. 1, D-18057 Rostock · GERMANY www.demographic-research.org

DEMOGRAPHIC RESEARCH

SPECIAL COLLECTION 3, ARTICLE 9

PUBLISHED 17 APRIL 2004, PAGES 213-244

www.demographic-research.org/special/3/9/

DOI: 10.4054/DemRes.2004.S3.9

Research Article

\title{
Becoming a Mother in Hungary and Poland during State Socialism
}

\section{Livia Sz. Oláh \\ Ewa Fratczak}

This special collection is in honor of Jan M. Hoem on his $65^{\text {th }}$ birthday. The authors presented their papers at a working party at the Max Planck Institute for Demographic Research in Rostock, Germany in April 2004. The collection is edited by Gunnar Andersson and Gerda Neyer.

(C) 2004 Max-Planck-Gesellschaft. 


\section{Table of Contents}

1 Introduction $\quad 214$

2 Theoretical model $\quad 214$

3 The comparative setting 216

$4 \quad$ Data and method $\quad 218$

5 Variables 220

$6 \quad$ Findings and discussion $\quad 222$

6.1 Control variables 222

6.2 Explanatory variables and the time factor 226

$\begin{array}{lll}6.3 & \text { Interactions } & 227\end{array}$

$7 \quad$ Concluding remarks $\quad 230$

$8 \quad$ Acknowledgements 232

Notes 233

$\begin{array}{ll}\text { References } & 235\end{array}$ 
Demographic Research - Special Collection 3: Article 9

-- Contemporary Research on European Fertility -- Perspectives and Developments --

Research Article

\title{
Becoming a Mother in Hungary and Poland during State Socialism
}

\author{
Livia Sz. Oláh ${ }^{1}$ \\ Ewa Fratczak $^{2}$
}

\begin{abstract}
Note 1)
In this paper, we study the transition to motherhood in the first co-residential union in the dual-earner context of state socialism, namely in Hungary and Poland between the late 1960s and the end of the 1980s. Our analyses are based on data extracted from the Polish and the Hungarian Fertility and Family Surveys of the early 1990s. We use the hazard regression method as our analytical tool.

Our results for Hungary indicate that women's employment does not necessarily reduce the propensity to become a mother if the combination of labor-force participation and family life has been facilitated by policy measures. In Poland however, this was more difficult, and state support was somewhat less generous, thus part-time workers and housewives had substantially higher first-birth intensity than full-time employed women. Even so, we find indication for Poland, that as policy measures increasingly improved the conditions to combine employment and family responsibilities, the propensity to have the first child increased. The timing of first birth varied greatly across educational levels. Highly educated women were more likely to postpone the transition to motherhood, which in turn resulted in their overall lower propensity to have the first child in both countries, but less so in Hungary than in Poland.
\end{abstract}

1 Research Fellow, Ph.D. Dept. of Sociology Stockholm University, S-106 91 Stockholm

Sweden. Tel.: +46 8 - 1628 76; Fax: +46 8 - 61255 80. E-mail: livia.olah@ sociology.su.se

2 Professor, Dr. Hab, Ph.D. Inst. of Statistics and Demography, Warsaw School of Economics -

SGH, Al.Niepodleglosci 162, 02-554 Warsaw, Poland. Tel: +48 22 - 33792 73;

Fax (and phone): +48 22 - 64661 38. E-mail: ewaf@ sgh.waw.pl 


\section{Introduction}

With the growing prevalence of the dual-earner family model and women's increasing economic independence in industrialized societies, couple relationships have been placed on new grounds, as compared to the male-breadwinner context of the past. The dual-earner model became dominant first in Central-Eastern Europe, as the region's governments followed the socialist ideology between the late 1940s and the late 1980s. Their commitment to the principle of full employment and gender equality, the latter limited to women's and men's equal labor-market participation, has led to changes in gender relations at both the societal level and in the family, as compared to the traditional single-earner model. Women's role has become much more important in the familial and national economy than it previously was. Nevertheless, the more equal share of domestic responsibilities does not accompany the more equal share of the economic provision of the family between women and men (Makkai 1994), similar to many Western countries where the dual-income family was established in the 1970s or later. Thus, studying the mechanisms of how the conditions of gender relations influenced childbearing decisions and behavior in state-socialist countries is also likely to enhance our understanding of the current trends of family formation in Europe in general. We focus on the first birth in the first co-residential union in Hungary and Poland from the mid-1960s to 1989.

\section{Theoretical model}

In our analysis we rely on a theoretical framework based on a combination of economic and ideational perspectives pointing to the importance of changing gender relations for childbearing decisions and behavior. We suggest that this is a universal issue, not strictly linked to a specific political or economic context, even though such approaches were created mostly in reference to market economies (Note 2). In our view, however, this model is equally suitable to study family formation in state socialism, as the underlying mechanisms of changes in gender relations are of a more general nature.

There are different stages in the process during which male-female relationship transform to become more equal. The first step is women's engagement in paid work, which strengthens a woman's bargaining position in the family. Yet if it is not accompanied by the awareness that the traditional division of the domestic burden, with women having the lion's share of it is unfair (stage 2), there is little chance that gender relations within the family will change substantially (stage 3). Family behavior and thereby demographic trends are affected, though, at each stage of this process. 
As argued in New-Home Economics, focusing on the American and WestEuropean context (Becker 1981), women's increasing economic independence, which is a consequence of their growing educational attainment and labor-force participation, has greatly increased the relative cost of children (via women's foregone earnings during the period they stay at home or work reduced hours in order to take care of their children). Fertility rates have therefore been declining dramatically in the industrialized world in the previous decades.

As pointed out by feminist scholars (see e.g. Baxter and Kane 1995), women's independence is, however, not only about women's increasing educational attainment and female labor market participation, even if these are its crucial components. Higher education facilitates the spread of ideas on gender equality, as the more educated are less likely to accept traditional gender arrangements that are disadvantageous for women, while employment provides women with a better bargaining position in a partnership via own earnings (Hobson 1990, Ahrne and Roman 1997). Further important dimensions of women's independence are the free choice of partnership form, access to means that enable women to control their fertility, and state policies (Note 3) that facilitate women's efforts to balance paid employment and family responsibilities (Baxter and Kane 1995).

In contrast to economic reasoning, empirical studies have shown that women's increasing economic independence can actually raise the benefits of family life, both for a family unit and for its individual members (see e.g. Oppenheimer 1994, Oláh 2001). Flexible gender roles can even promote childbearing if they are accompanied by public policies, where the institutional setting and provided services facilitate the combination of employment and parenthood, and thereby reduce the opportunity cost of becoming a mother (Bernhardt 1993, Joshi 1998). Thus, the dual-earner family model, which has been dominant in Hungary and Poland for several decades, is not necessarily accompanied by the reduced propensity of having an early first child, economic theories notwithstanding.

From another angle, but also implicitly pointing to the importance of gender relations, ideational changes, such as growing individualism and other value shifts, have been stressed as contributing to the emergence of new family patterns in Europe (Lesthaeghe 1983). The growing prevalence of non-marital cohabitation and livingapart-together (LAT) relationships, where a couple does not share a dwelling, resulted in a great diversity of partnerships, even for first unions. Childbearing has become more optional and less of an imperative, also for married couples given modern and more efficient contraceptives. On the other hand, births have more and more frequently occurred in non-marital unions, as its societal disapproval diminished and eventually disappeared (van de Kaa 1994). These trends emerged all over Europe, at a 
limited extent also in its eastern part (Note 4), influencing and influenced by gender relations, both at the societal level and within the family.

Thus, our main hypotheses for this analysis are the following: (i) Women's economic independence does not necessarily reduce the propensity to have an early first child, if public policies, via institutional setting and services, facilitate the combination of employment and family responsibilities. (ii) Because of changes in gender relations at both the societal level and within the family, individual values and attitudes are likely to become influential for childbearing decisions and behavior.

\section{The comparative setting}

We apply a comparative research design, and have selected Hungary and Poland for a number of reasons beyond the fact that we know both societies well and have access to the best data available for them for the socialist period. Their similarities and contrasts, as listed below, can help us to avoid generalizations based on results specific to a single country alone, and make it easier to detect patterns and mechanisms of a more general trend.

Although both Hungary and Poland belonged to the Central-East European demographic regime, where marriage was early and almost universal, the level of childlessness was low, and childbearing was limited to relatively young ages (below the mid-thirties), there were some variations in their demographic patterns. The mean age at first marriage and that at first birth were lower in Hungary than in Poland, but the Polish total fertility rate nearly always exceeded that of Hungary, and belowreplacement fertility has been experienced there only since the late 1980s. First-birth rates were, however, somewhat higher in Hungary than in Poland, except for the 1980s. (See Figures A-C in the Appendix.) Non-marital cohabitation as first partnership was rare in Poland, perhaps due to the strong position of Catholicism there, but less so in the more secularized Hungary, where such unions became more common in the 1980s. The age of sexual début was below that of marriage, while outof-wedlock childbearing was not socially approved in either society in the socialist period. Contraceptive practices of young unmarried couples were quite different in the two countries. In Poland, contraceptive use before the first birth was less prevalent than in Hungary. Young couples in Poland mostly relied on traditional methods such as periodic abstinence and coitus interruptus, while the pill and other modern contraceptives were frequently used by Hungarian youths. Abortion was a less sensitive topic in Hungary since the late 1950s, and it was a socially accepted, although not approved, option for family-size limitation. This was less so in Poland even before it 
became severely restricted in the early 1990s (Kuciarska-Ciesielska 1993, Kamarás 1999).

In the state-socialist period (i.e. before 1990), gender equality defined as equal labor-force participation of women and men, was an important principle of public policy making. As a consequence of the generally low level of wages and limited opportunities of part-time work, the full-time working dual-earner family model was established in Central-Eastern Europe as early as the 1950s-1960s, while domestic tasks (incl. childrearing) remained a woman's domain (Gal and Kligman 2000). The proportion of women who chose to become full-time housewives after marriage or birth was rather small, and this was more so in Hungary than in Poland. Social benefits (even family allowance and access to public childcare) were linked to laborforce attachment.

The level of education attained increased over cohorts among both women and men in Hungary and Poland to meet the changing demands of the labor market. A gendered pattern in education was most apparent at the secondary-school level, with men more often attending vocational schools and women attending upper-level secondary schools. The gap between the proportions of highly educated women and men diminished rapidly, and by the early 1990s the share of women with postsecondary education nearly surpassed that of men among those below age 40 (Holzer and Kowalska 1997, Kamarás 1999). Educational attainment also influenced the level of incomes. Although wage-differences were greatly suppressed in state-socialist countries, the gap between the earnings of the least educated and those with secondary or higher education was still quite considerable, at least for women. The earnings of men, who worked as miners, or in other key sectors of the economy, were among the highest ones independently of educational level.

Family formation was constrained by a severe housing shortage in both countries. Newly-weds often had to wait several years before having a dwelling of their own. In the meantime, young couples mostly lived with the wife's, or husband's parents (Ratajczak 1993, Kamarás 1999). In the countryside, private housing dominated, whereas there were substantial differences regarding home-ownership in urban areas. In Poland, the majority of dwellings was owned and rented out by municipalities and by state enterprises (in the latter case only their employees were eligible). Rental housing was less common in Hungary, where quasi-market solutions in housing provision, such as housing co-operatives (where individuals bought the dwelling, or the right to live there), played an increasingly important role since the 1960s. Private housing was backed up by low-interest-rate bank-loans in Hungary. From the early 1970s, part of the loan functioned as a kind of baby-bonus, a one-time benefit not to be repaid if the couple had children within a certain number of years after taking the loan (one child within 3 years or 2 children within 6 years). The amount of this bonus 
depended on the number of children actually born to the couple (Tárkányi 2001/2002; Oláh et al. 2002).

Public policies regarding the care for children addressed mothers in the first place, but policy-makers followed different strategies in the two countries, except for the first few months following a birth, when a fully paid maternity leave was provided. In Hungary, from the late 1960s, mothers had the right to an extended leave of absence from employment beyond the 5 month-long maternity leave up to the third birthday of a child. Job-guarantee and a flat-rate benefit were attached to the child-care leave. In 1982, fathers also became eligible, but only after the first birthday of a child. In 1985, another child-care leave program was introduced, covered by an income-related benefit of 75 per cent of the previous earnings. The benefit was provided until the first birthday of a child (Sándorné Horváth 1986, Klinger 1991). The eligibility-period was extended by a half year in 1986, when fathers also became eligible, and was extended again in 1987, up to the child's second birthday. Subsidized public childcare, run by municipalities and large companies, was provided mainly for children aged three years and above (Adamik 1991).

In Poland, public childcare provision that included children below age three, was an important policy issue in spite of its limited availability (Note 5), while statesupport for the home care of young children was not considered essential and remained less generous than in Hungary. After the end of the 12-weeklong maternity leave, employed mothers could take an unpaid child-care leave with job-guarantee up to the first birthday of a child, up to 1972, thereafter to the third birthday of a child. At the same time, maternity leave was extended to 16 weeks at first birth and to 18 weeks at the second and higher-order births. In 1981, a means-tested flat-rate benefit was introduced for mothers on child-care leave, and later on fathers became eligible (Holzer 1991, Balcerzak-Paradowska 1998). The proportion of fathers taking childcare leave was extremely low in both countries, not only because of men's usually higher earnings, which in itself would increase the economic loss for a family as compared to the mother using the leave. Thus, despite high female employment rates for several decades, and relatively high level of gender equality in the public sphere, the division of family responsibilities remained rather traditional and was even reinforced by public policies in Hungary and Poland, similarly to other Central-East European countries (Watson 1993).

\section{Data and method}

The empirical analysis in this study is based on data extracted from the Hungarian Fertility and Family Survey of 1992/93, conducted by Statistics Hungary, and from the 
Polish Fertility and Family Survey of 1991, conducted by the Institute of Statistics and Demography, Warsaw School of Economics (SGH) in cooperation with the Central Statistical Office, Poland. Both surveys are part of the European Fertility and Family Surveys Program, organized by the Population Activities Unit of the United Nations Economic Commission for Europe, which facilitates data comparability. The surveys contain complete union, childbearing, education, and work histories of 3554 women from Hungary and 4209 women from Poland. Men were also interviewed, but in Poland childbearing histories were not recorded for them. Thus, the male data cannot be used in this comparative study (Note 6). The response rate was around 90 per cent for women in both countries.

The Hungarian sample was nationally representative for the 18-41 year old female population, selected partly through one-stage proportional sampling (for the capital and the largest cities), and partly through two-stage stratified sampling (for the rest of the country). In the first stage of the stratified sampling, the sampling areas were stratified according to the number of inhabitants, and municipalities were randomly selected from each stratum. The final sample was drawn at random using the National Population Register as the sampling frame (Kamarás 1999). The Polish sample, selected in two stages, consisted of 4313 households. First, representative districts were selected, then dwelling units in these districts were drawn and all members of a household aged 18-49 were interviewed (Fratczak et al. 1996, Holzer and Kowalska 1997).

In conducting our study of first birth in first union (Note 7) in the socialist period, we selected respondents who reported one or more co-residential relationships (2988 in Hungary, and 3424 in Poland), were born in 1950 or later, and who entered their first union before December 1989 (Note 8). Respondents whose first partner had a child from a previous partnership (144 and 79 women for Hungary and Poland respectively) were excluded, as the decision to become a mother in a latter relationship is likely to be rather different as compared to a union where the partners are childless when entering the union (see Thomson et al. 2002). We have also excluded respondents whose first child was born before or in the same month they entered their first union (71 for Hungary, 138 for Poland), as well as those with incomplete union records ( 2 for Poland). Thus, a total of 2422 women have been included in the Hungarian working sample and 2090 women in the Polish one. About 83 per cent of the Hungarian sample and 93 per cent of the Polish sample had their first child during the period of observation.

The analysis is based on a piecewise-constant proportional hazards model. Exposure is measured in months, starting at the formation of the first co-residential union of the respondent and continued until the birth of her first child, or until censoring at nine months after the dissolution of first union or after the death of the first partner, or at the end of 1989 (i.e. the end of the socialist period), whichever event 
comes first. We have partitioned this range into the following intervals: 1-7, 8-18, 19$24,25-36,37-48,49-60,61-120$ and $121+$ months. We behave as if the intensity of first childbearing is constant over each of these pre-selected time intervals, but let it vary between intervals. Information for those who did not become a mother during the period of observation is also taken into account.

Our computations are based on exposures in half-month units. We pretend that all recorded demographic and other events occurred at the middle of a calendar month, while changes in period variables occur at the beginning of a calendar month. The Windows-based software "RocaNova", developed at Statistics Sweden, is used to fit the model. The results, produced as maximum-likelihood estimates of the effect parameters of the model, are presented in the form of relative risks. The samples are analyzed separately for the two countries.

\section{Variables}

Our main variables of interest are educational attainment, employment status and calendar period as measures of women's economic independence, all time-varying covariates. In addition, we include two attitude variables in the model: religiosity and respondent's opinion about abortion. (For details see Table A in the Appendix.) These are fixed factors, measured at the interview, and therefore may be somewhat problematic, especially the attitude to abortion, as respondents may have adjusted their attitudes to their previous behavior in a kind of "post-hoc rationalization". Thus, we shall be cautious in our interpretation of the results.

The variable current educational attainment refers to the highest level of schooling a respondent had in any month in the period of observation. It can also be seen as a proxy for income. In the demographic literature regarding the link between first-birth rates and women's education in Western countries, high level of schooling was found to reduce the propensity to become a mother e.g. in the US and Sweden in the 1960s and 1970s (Rindfuss and St. John 1983, Bloom and Trussell 1984, Hoem 1992), except for higher ages (Etzler 1987, Rindfuss et al. 1988). In the 1980s and 1990s however, the impact of women's educational level on first-birth rates greatly diminished (Kravdal 1994, Rindfuss et al. 1996, Thomson and Hoem 1998, Santow and Bracher 2001). We do not expect such radical change over time in the effect of educational attainment on first-birth fertility in Hungary and Poland, given both women's and men's strong labor-force attachment (mostly full-time work) during state socialism, educational level notwithstanding. While more highly educated women, given their higher income, had a more favorable economic situation to have a child than less educated women had, the higher demand the highly educated faced in their 
career-type jobs was likely to reduce their childbearing propensity, especially since household duties were women's responsibility, usually without help from their men. Our empirical analysis will show which one of these countervailing effects was stronger regarding the first birth in state socialism.

Our other measure of women's economic independence, current employment status, shows the respondents' labor-market attachment in any month while not (yet) being a parent. As a pregnancy has not commonly led to changes in one's employment strategies, and all socialist countries provided paid maternity leave for several months after a birth and often additional child-care leave, women who were most often employed full-time, similarly to men, had no reason to give up their work due to the transition to motherhood. While women's employment has been found to reduce first-birth intensity in countries like Spain and Canada (Castro Martín 1992, $\mathrm{Wu}$ and MacNeill 2002) where female labor-force participation has been a relatively recent development, a positive impact was shown for Sweden (Andersson 2000, Hoem 2000), given her long history of women's employment and policy measures facilitating the combination of paid work and family responsibilities. We do not expect employment to be an impediment to becoming a mother in Hungary, or Poland either, as the dual-earner model, backed-up with supportive policies (see Section 3), had been dominant in state socialism. Attending school, however, is likely to reduce the intensity of first birth, in line with findings for other countries (Blossfeld and Jaenichen 1992, Santow and Bracher 2001), as this link is less context-specific and of a more general nature.

The impact of state policies is measured via our current calendar period variable, which is defined in consideration of changes in housing availability and in the parental-leave program, as they can be expected to affect childbearing decisions and behavior (Hoem 1993). The improvement in housing availability over time (Note 9), except for the last period (i.e. the fourth and the third categories of this variable for Hungary and Poland, respectively), as well as the increasingly generous rules of the child-care leave program (for details see Section 3), are likely to have stimulated first childbearing as the conditions of family formation improved. The importance of individual attitudes may also have increased over time. We expect that young women with more traditional attitudes had a higher propensity to have an early first child than those with more liberal attitudes, as reflected by the variables religiosity and attitude to abortion.

Besides these factors, a woman's sexual and partnership behavior is likely to influence her transition to motherhood. We apply three measures, which are all fixed variables; namely birth control use at her sexual début, her age at first co-residential union formation and the type of her first partnership. The impact of birth control use at the first sexual experience on the first birth has not been extensively studied, as this 
information was not frequently available. Therefore, we can only speculate regarding its effect on the transition to motherhood. Supposing that the use of a particular contraceptive method, or none at the sexual début, reflects the extent to which a woman "plans" her first pregnancy that leads to her first birth, we expect those not using any contraceptive at their first sexual experience to also have a higher first-birth intensity than individuals using some form of birth control method, especially those using modern, effective contraceptives, given the lower risk of unplanned pregnancy for the latter group. The formation of the first co-residential union at young ages might mean that the respondent has a more regular sex life, or a less efficient contraceptive use than those who enter first partnership at higher ages and therefore is likely to have a higher first-birth intensity than the latter group. Also fecundity diminishes by age, but this is less of a concern below age 30 (Menken 1985), and most women had already had their first child by that age in state-socialist countries. As for the type of first union, we know that marriage has been the dominant family form in the socialist period, even though cohabitation was also accepted in Hungary in the 1980s, but less so in Poland. Childbearing has remained associated with marriage, however (Klinger 1991, Liefbroer and Fratczak 1996). Thus, we expect the propensity of becoming a mother to be lower in unions that began as cohabitation.

We use a stepwise approach for the model fitting. First we include only individual background characteristics: birth cohort, childhood family and number of siblings. Then, we add our variables of sexual and partnership behavior to the model. Such stepwise introduction of factors into the model reflects the sequence in which they appear in a respondent's life. This, in turn, determines their causal proximity to the current life situation of the respondents. In addition, our procedure allows us to exclude those factors that do not have a significant impact on first childbearing. Cohort, however, will not be included at later steps, regardless of possible significance, as adding calendar period together with age at first union formation and duration of first union (i.e. our time variable) would otherwise result in an over-determined model. In the final step only the important control variables are kept in the model, as we add our final main explanatory variables.

\section{Findings and discussion}

\subsection{Control variables}

As we see in Table 1, own birth cohort was an important factor for first childbearing in Poland, showing an increasing intensity over cohorts, but not in Hungary. In both countries, childhood family mattered very little for the transition to motherhood 
(Model 1). Number of siblings, however, proved to be influential, showing a positive gradient (Models 1-3), as women with more siblings were probably more familyoriented than those who grew up in small families, and therefore had a higher propensity to have the first child shortly after union formation than the latter group. The positive effect appears for Poland only for those with three or more siblings, while for Hungary we see it also for women with at least two siblings. This may display differences in what was perceived as a "small family" in these two countries.

Factors reflecting sexual and partnership behavior also affected the intensity of first birth in both countries (Models 2-3). Birth control at first sex seems to be more important for Hungarian women's childbearing behavior than for Polish women who were less likely to use contraceptives before their first birth (Kuciarska-Ciesielska 1993, Kamarás 1999). Hungarian women who relied on the pill or IUD at their sexual début had the lowest propensity to become a mother early on. The use of the condom or of traditional methods also reduced the intensity of first birth, as compared to those who did not use any contraceptive. For Polish women, compared to those who used no contraceptive, the propensity to have a first child is significantly lower only among those who used an IUD or the pill. This group, however, represents very different proportions of women in their countries, including about 30 per cent of Hungarian women, but less than 2 per cent of Polish women who entered a first union in the socialist period. These country differences suggest that the first pregnancy leading to the first birth was more likely to be "planned" in Hungary than in Poland.

For age at first union formation we find that, as expected, women who entered their first co-residential relationship at young ages had the highest propensity to have a first child in both countries. With increasing age at union start, the intensity of first birth decreased, and more so in Poland than in Hungary.

For the type of first partnership we see that the propensity to become a mother is highest in direct marriages (i.e. when the couple has moved in together at the time of the marriage formation) for both countries, as expected. The first-birth intensity in relationships that started with cohabitation is somewhat more reduced in Hungary than it is in Poland, as compared to direct marriages. We can only speculate about the reasons for such possible difference between the two countries. These couples may be a select group in Poland (they are rather few indeed), who are reluctant or unable (e.g. due to difficulties to dissolve the partner's previous marriage given religious constraints) to enter marriage, but do not want to refrain from childbearing. In Hungary, couples not inclined to become parents for quite some time seem to choose to cohabit instead of getting married. 
Demographic Research - Special Collection 3: Article 9

-- Contemporary Research on European Fertility -- Perspectives and Developments --

Table 1: $\quad$ First-birth intensities for Hungarian and Polish women in their first coresidential relationship. Relative risks.

\begin{tabular}{|c|c|c|c|c|c|c|}
\hline & (1) & (1) & (2) & (2) & (3) & (3) \\
\hline & Hungary & Poland & Hungary & Poland & Hungary & Poland \\
\hline cohort: & $(p=0.665)$ & $(p=0.000)$ & & & & \\
\hline $1950-1954$ & 1 & 1 & & & & \\
\hline $1955-1959$ & 0.98 & $1.11^{*}$ & & & & \\
\hline $1960-1964$ & 0.97 & $1.26^{\star \star \star}$ & & & & \\
\hline $1965-1969$ & 0.91 & $1.38^{\star \star *}$ & & & & \\
\hline $1970-1973$ & 0.82 & 1.55 & & & & \\
\hline childhood family: & $(p=0.678)$ & $(p=0.782)$ & & & & \\
\hline intact family & 1 & 1 & & & & \\
\hline parents divorced & 0.95 & 1.04 & & & & \\
\hline other non-intact & 0.95 & 0.95 & & & & \\
\hline siblings: & $(p=0.000)$ & $(p=0.000)$ & $(p=0.000)$ & $(p=0.000)$ & $(p=0.001)$ & $(p=0.002)$ \\
\hline none & 0.94 & 0.92 & 0.94 & 0.85 & & \\
\hline one $/<$ two & 1 & 1 & 1 & 1 & 1 & 1 \\
\hline two & $1.13^{* \star}$ & 1.05 & $1.15^{\star \star}$ & 1.06 & $1.13^{\star *}$ & 1.07 \\
\hline three + & $1.32^{\star \star \star}$ & $1.35^{\star \star *}$ & $1.29^{* \star *}$ & $1.32^{* \star \star}$ & $1.25^{* \star *}$ & $1.26^{* *}$ \\
\hline \multicolumn{7}{|l|}{ birth control at 1st } \\
\hline sex: & & & $(p=0.000)$ & $(p=0.028)$ & $(p=0.000)$ & $(p=0.074)$ \\
\hline non-use & & & 1 & 1 & 1 & 1 \\
\hline traditional methods & & & $0.82^{* \star \star}$ & 0.96 & $0.84^{\star *}$ & 1.00 \\
\hline condom or chemica & measures & & $0.81^{* *}$ & 1.06 & $0.85^{\star}$ & 1.07 \\
\hline pill or IUD & & & $0.73^{\star * *}$ & $0.60^{* \star *}$ & $0.76^{\star * *}$ & $0.64^{\star \star \star}$ \\
\hline \multicolumn{7}{|l|}{ age at 1 st union } \\
\hline formation: & & & $(p=0.000)$ & $(p=0.031)$ & $(p=0.000)$ & $(p=0.022)$ \\
\hline below 18 years & & & $1.29^{* \star \star}$ & 1.15 & $1.28^{* \star \star}$ & 1.15 \\
\hline $18-20$ years & & & 1 & 1 & 1 & 1 \\
\hline $21-25$ years & & & $0.84^{* \star \star}$ & 0.95 & $0.86^{* \star *}$ & 0.97 \\
\hline $26-31$ years & & & 0.84 & $0.81^{* *}$ & 0.89 & $0.79^{* *}$ \\
\hline $32+$ years & & & 0.88 & $0.59^{*}$ & 0.72 & $0.52^{* \star}$ \\
\hline \multicolumn{7}{|l|}{ type of 1st } \\
\hline partnership: & & & $(p=0.000)$ & $(p=0.000)$ & $(p=0.000)$ & $(p=0.000)$ \\
\hline direct marriage & & & 1 & 1 & 1 & 1 \\
\hline \multicolumn{7}{|l|}{ union begun as } \\
\hline \multicolumn{7}{|l|}{ current educational } \\
\hline attainment: & & & & & $(p=0.001)$ & $(p=0.000)$ \\
\hline primary school & & & & & 1 & 1 \\
\hline lower-secondary & & & & & 1.09 & $0.81^{* \star *}$ \\
\hline upper-secondary & & & & & $0.86^{* *}$ & $0.73^{* \star *}$ \\
\hline tertiary education & & & & & $0.82^{* \star}$ & $0.59^{\star * \star}$ \\
\hline
\end{tabular}


Demographic Research - Special Collection 3: Article 9

-- Contemporary Research on European Fertility -- Perspectives and Developments --

Table 1: (Cont.)

\begin{tabular}{|c|c|c|c|c|c|c|}
\hline & (1) & (1) & (2) & (2) & (3) & (3) \\
\hline & Hungary & Poland & Hungary & Poland & Hungary & Poland \\
\hline current & & & & & & \\
\hline employment stat & & & & & $(p=0.005)$ & $(p=0.001)$ \\
\hline full-time employec & & & & & 1 & 1 \\
\hline part-time employe & & & & & 1.19 & $1.41^{*}$ \\
\hline unemployed & & & & & 0.60 & 1.38 \\
\hline student & & & & & $0.71^{* \star *}$ & $0.74^{\star * *}$ \\
\hline housewife & & & & & 1.01 & $1.33^{* *}$ \\
\hline other non-employe & & & & & $1.27^{\star \star}$ & $1.14^{*}$ \\
\hline current calendar & & & & & & \\
\hline period: & & & & & $(p=0.387)$ & $(p=0.000)$ \\
\hline H: 1967-71; P: 19 & -72 & & & & 0.80 & $0.80^{* *}$ \\
\hline H: 1972-82; P: 19 & -81 & & & & 1 & 1 \\
\hline H: 1983-85; P: 19 & -89 & & & & 0.94 & $1.17^{* * *}$ \\
\hline H: 1986-89 & & & & & 0.99 & \\
\hline religiosity: & & & & & $(p=0.295)$ & $(p=0.510)$ \\
\hline active & & & & & 1 & 1 \\
\hline not active & & & & & 0.94 & 0.96 \\
\hline attitude to aborti & & & & & $(p=0.266)$ & $(p=0.431)$ \\
\hline restrictive & & & & & 1 & 1 \\
\hline allowing for unma & & & & & 1.14 & 0.84 \\
\hline liberal & & & & & 1.02 & 0.96 \\
\hline other & & & & & 1.11 & 1.12 \\
\hline $\begin{array}{l}\text { duration of 1st } \\
\text { union in months }\end{array}$ & & & & & & \\
\hline (time factor): & $(p=0.000)$ & $(((p=0.000)$ & $(p=0.000)$ & $(p=0.000)$ & $(p=0.000)$ & $(p=0.000)$ \\
\hline 1 - 7 months & $0.51^{\star * *}$ & $0.50^{* \star *}$ & $0.48^{* * *}$ & $0.50^{* \star *}$ & $0.48^{* * *}$ & $0.50^{* \star *}$ \\
\hline $8-18$ months & 1 & 1 & 1 & 1 & 1 & 1 \\
\hline $19-24$ months & $0.81^{* \star *}$ & $0.63^{* * *}$ & $0.84^{* *}$ & $0.64^{\star \star *}$ & $0.84^{* *}$ & $0.65^{\star \star *}$ \\
\hline 25 - 36 months & $0.66^{* * *}$ & $0.51^{* * *}$ & $0.71^{* * *}$ & $0.51^{\star \star *}$ & $0.71^{* * *}$ & $0.52^{* * *}$ \\
\hline 37 - 48 months & $0.54^{* * *}$ & $0.40^{* * *}$ & $0.58^{* \star *}$ & $0.40^{* \star *}$ & $0.58^{* \star *}$ & $0.41^{* * *}$ \\
\hline 49 - 60 months & $0.43^{* * *}$ & $0.32^{* \star *}$ & $0.46^{* \star *}$ & $0.32^{* \star *}$ & $0.47^{* * *}$ & $0.33^{* \star *}$ \\
\hline $61-120$ months & $0.30^{* \star *}$ & $0.15^{\star \star \star}$ & $0.31^{\star \star \star}$ & $0.14^{* \star *}$ & $0.32^{* * *}$ & $0.14^{* * *}$ \\
\hline $121+$ months & $0.05^{\star \star *}$ & $0.11^{* * *}$ & $0.05^{\star \star *}$ & $0.10^{* \star *}$ & $0.05^{\star \star *}$ & $0.09^{* * *}$ \\
\hline & [27.199] & [33.534] & [33.695] & [41.648] & [35.133] & [52.087] \\
\hline log likelihood: & -9812.0 & -8670.2 & -9722.6 & -8658.3 & -9701.1 & -8623.0 \\
\hline no. of independe & & & & & & \\
\hline parameters: & 17 & 17 & 19 & 19 & 33 & 32 \\
\hline
\end{tabular}

${ }^{* * *}$ significant at the $1 \%-l e v e l,{ }^{* *}$ at $5 \%,{ }^{*}$ at $10 \%$.

Note: For each variable, risks and their significance are given relative to the reference level, indicated by 1 (no decimals). The $p$ value of the entire factor is given in the row containing the variable name. Absolute risk (per 1000 person-half-months) for duration 8-18 months in first union is given in the last row of the time factor in boldface letter. 


\subsection{Explanatory variables and the time factor}

As for our explanatory variables (Model 3), we find that current educational attainment had a significant impact on first childbearing in both Hungary and Poland in state socialism. While we see a clear negative gradient for Poland, the intensity to have the first child is nearly the same for those with primary education or with a lower-secondary education in Hungary. Women with upper-secondary education have a circa 15 per cent lower propensity to have the first child in Hungary, and an approximate 25 per cent lower propensity in Poland than those with the least education. Among the most highly educated, the first-birth intensity is 18 and 41 per cent lower in Hungary and Poland, respectively, than among women with only primary education. This suggests that highly educated women in a conjugal union have a very different pattern of timing their first birth than those with less education, as they are more likely to postpone their transition to motherhood in order to better cope with the demands of their jobs at the start of their career. This pattern appeared more clearly in Poland than in Hungary. Delaying the first birth, in turn, may result in a somewhat higher level of childlessness among such women than among other educational groups of women.

Current employment status has proved to be very important for the propensity to become a mother in both countries. As expected, students had the significantly lowest first-birth intensity (around 25 per cent lower intensity than full-time employed women). In Poland, the relatively small group of housewives and that of part-time employed had a more than 30 per cent higher propensity to have a first child than childless women working full time. We find no significant difference for either of these groups in Hungary, possibly because only those with sufficient labor-market experience, namely at least a year of full-time employment before childbearing, have qualified for the child-care allowance (i.e. the parental-leave benefit). In Poland, however, state support for the home-care of children was much less generous than in Hungary (see Section 3). Therefore, gaining eligibility through full-time employment for a longer period before first childbearing was also less important for young women. In addition, the results may indicate that the combination of full-time employment and family responsibilities were somewhat more difficult in Poland than in Hungary given the different conditions of daily life linked to differences in overall living standards in the two countries during the socialist period (Radványi 1992, Marody and GizaPoleszczuk 2000).

Current calendar period had little influence on first childbearing in Hungary, notwithstanding the (except for the last period) improving housing availability and the increasingly generous child-care leave program, yet it appears to be significant for Poland. There we see that the propensity to have the first child was 20 per cent lower 
during calendar years when women could take unpaid child-rearing leave only until the $1^{\text {st }}$ birthday of a child (i.e. up to 1972), as compared to the period when the leave was extended to three years (i.e. in the 1970s). After the introduction of a means-tested benefit in the early 1980s, first-birth intensity increased further by nearly 20 per cent, in spite of the economic recession the country experienced at that time (Holzer and Kowalska 1997).

Our attitude variables, religiosity and attitude to abortion, do not seem to have any impact on the transition to motherhood in either country. This may reflect the strength of the Central-East European demographic regime, as people with different attitudes were following a rather similar pattern in their childbearing behavior in the socialist period, with young age at first birth and an overall low level of childlessness. Alternatively, the relatively recent exposure of the state-socialist countries to "Western" influences, including individualism and other 'new' values and ideals, minimized the effect of various individual attitudes on the transition to motherhood.

Our time variable (duration of first union in months) shows that the first-birth intensity is highest in the period of 8-18 months in the first co-residential relationship (it shows especially strongly for Poland) and decreases thereafter (models 1-3). After 3 years in the union, the intensity to have the first child is about half of that seen for the period of 8-18 months in the relationship. After 10 years in first partnership, the propensity to become a mother is extremely low in both countries. The latter couples are likely to have problems with fecundity or decided to remain childless for some reason. Thus, first birth seems to occur very early in first union in both Hungary and Poland. Those who wait longer are likely to forgo parenthood altogether, at least in their first partnership (see also Oláh and Fratczak 2003).

\subsection{Interactions}

We have also tested for possible interaction effects between our main explanatory variables, type of first partnership, and the time factor in order to gain further insights in the patterns of family formation in state socialism. None of the interactions where either of the attitude variables was included turned out to be informative or interesting, which strengthens our conclusions regarding the minimal effect of these factors on first childbearing, as discussed above.

Focusing on variations in the timing of first birth, the general picture from the main effect model is confirmed, i.e. couples seem to have aimed at having a child soon after they entered their first union (see the peak at 8-18 months in the union) in both Hungary and Poland. Such behavior was more pronounced for women with lower 
Risks relative to primary education, 8-18 months in first union, Hungary

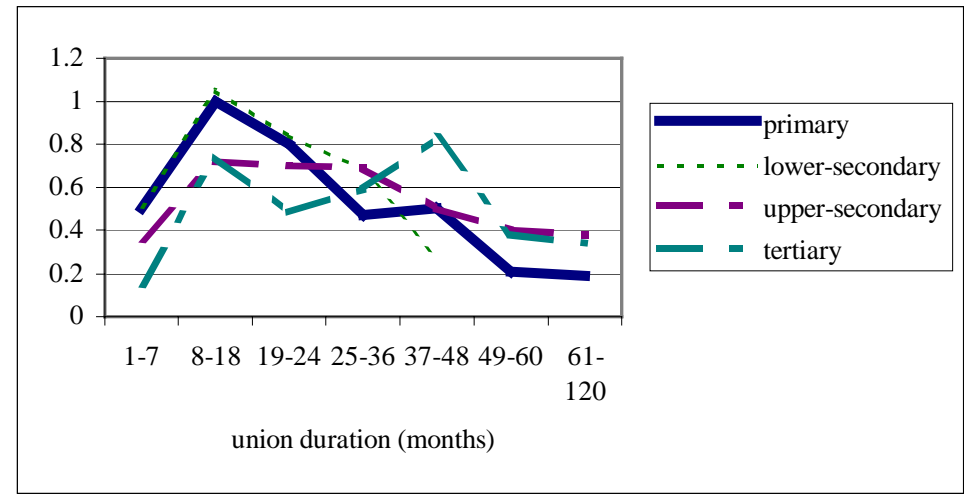

Risks relative to primary education, 8-18 months in first union, Poland

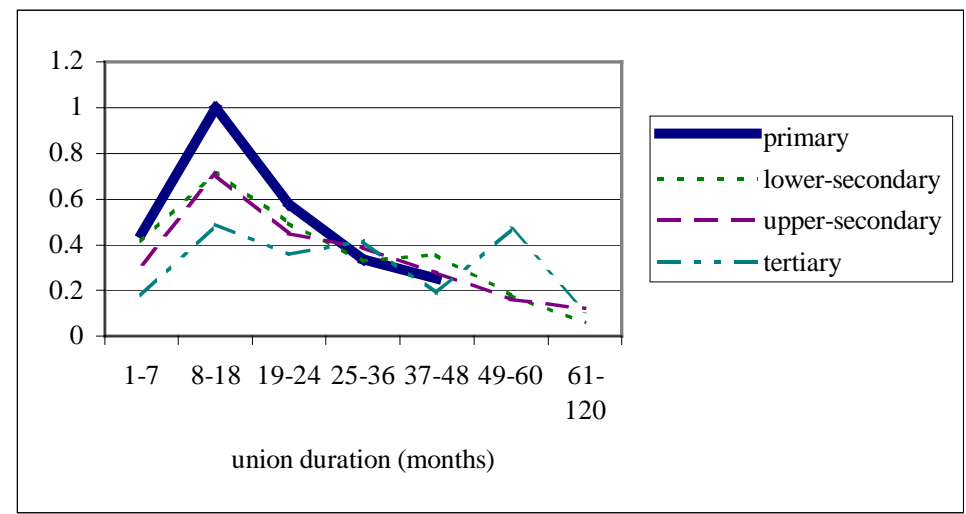

Figure 1: $\quad$ First-birth intensities in first co-residential union for Hungarian and Polish women, by current educational attainment and duration of first union*.

Standardized for the respondent's number of siblings, age at first union formation, type of first partnership, birth control at first sex, attitude to abortion, religiosity, current calendar period and current employment status.

Note: $p=0.000 \& 0.004$ for Hungary and Poland, respectively

* Cells with very little exposure time are not shown. 
Risks relative to direct marriage, 8-18 months in first union, Hungary

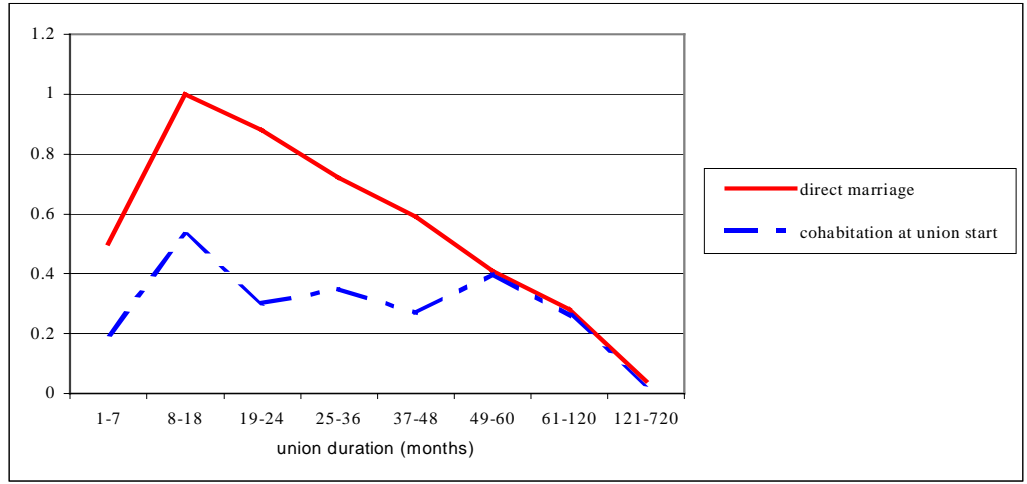

Risks relative to direct marriage, 8-18 months in first union, Poland

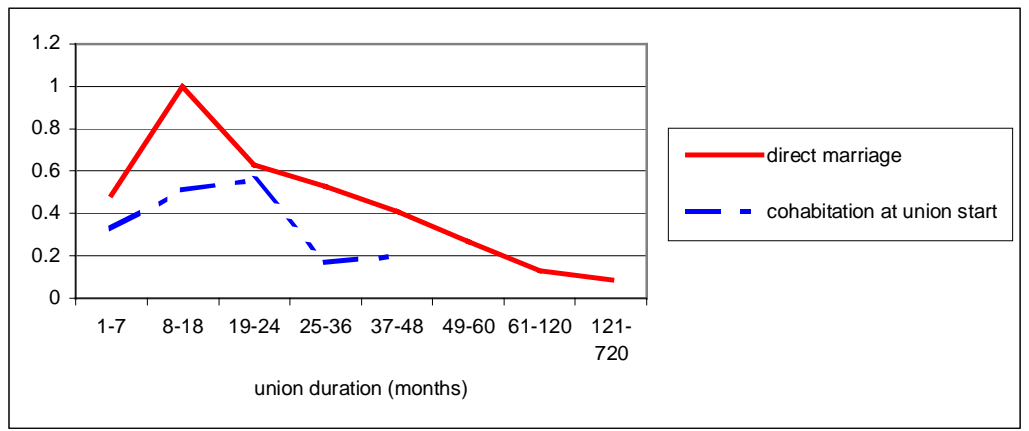

Figure 2: $\quad$ First-birth intensities in first co-residential union for Hungarian and Polish women, by type of first partnership and duration of first union*.

Standardized for the respondent's number of siblings, age at first union formation, birth control at first sex, attitude to abortion, religiosity, current calendar period, current educational attainment and current employment status.

Note: $p=0.065 \& 0.021$ for Hungary and Poland, respectively

${ }^{*}$ Cells with very little exposure time are not shown. 
levels of schooling than for the more highly educated (Figure 1), and was mainly related to marriage formation, and less so to non-marital unions (Figure 2).

For Hungary, we find one additional interaction effect. The interaction between current calendar period and employment (Figure 3) shows that the propensity to become a mother increased greatly for full-time employed women in the 1970s as compared to the late 1960s, but remained stable later on, notwithstanding changes in the child-care leave program and housing availability. The intensity of first birth increased, however, for the small group of part-time-working women in the late 1980s when the income-related child-care leave benefit was introduced. Students were not eligible for this benefit. A flat-rate benefit, introduced in the late 1960s and increased only moderately over time, could not cover increasing living expenses (Andorka 1996). This may have contributed to students having a much lower first-birth intensity in the 1980s than in the 1970s. In any case, students and housewives had the lowest propensity to become a mother in the 1970s and early 1980s among all employment statuses.

For Poland, we find that the intensity of first birth increased over calendar periods for directly married women only, but not for those in unions that began as cohabitation (Figure not displayed here). We have no explanation for this pattern, as the rules of child-care leave were not distinguished by a mother's marital status, but applied to all women equally. We can only speculate about possible differences in housing availability, namely that married couples may have had better access to proper housing than cohabiting couples, which may have influenced their childbearing behavior.

\section{Concluding remarks}

In this paper, we have studied the transition to motherhood in first union in Hungary and Poland during state socialism. In these countries, the traditional demographic regime characterized by early and nearly universal marriage, childbearing limited to ages up to the mid-thirties and a low level of childlessness, had been accompanied by a policy regime that encouraged equal labor-force participation of women and men, but not their equal share of family work, and provided means for young people to control their fertility if they wished.

In contrast to economic theories, our findings suggest that women's economic independence is not bound to reduce the propensity of first birth in the dual-earner family context, when the combination of employment and family responsibilities is facilitated for women by policy measures. However, a less generous state-support and/or difficulties to combine full-time work and family tasks may reduce the firstbirth intensity of full-time employed women, as compared to that of women with 
Demographic Research - Special Collection 3: Article 9

-- Contemporary Research on European Fertility -- Perspectives and Developments --

Risks relative to full-time employed, 1972-82

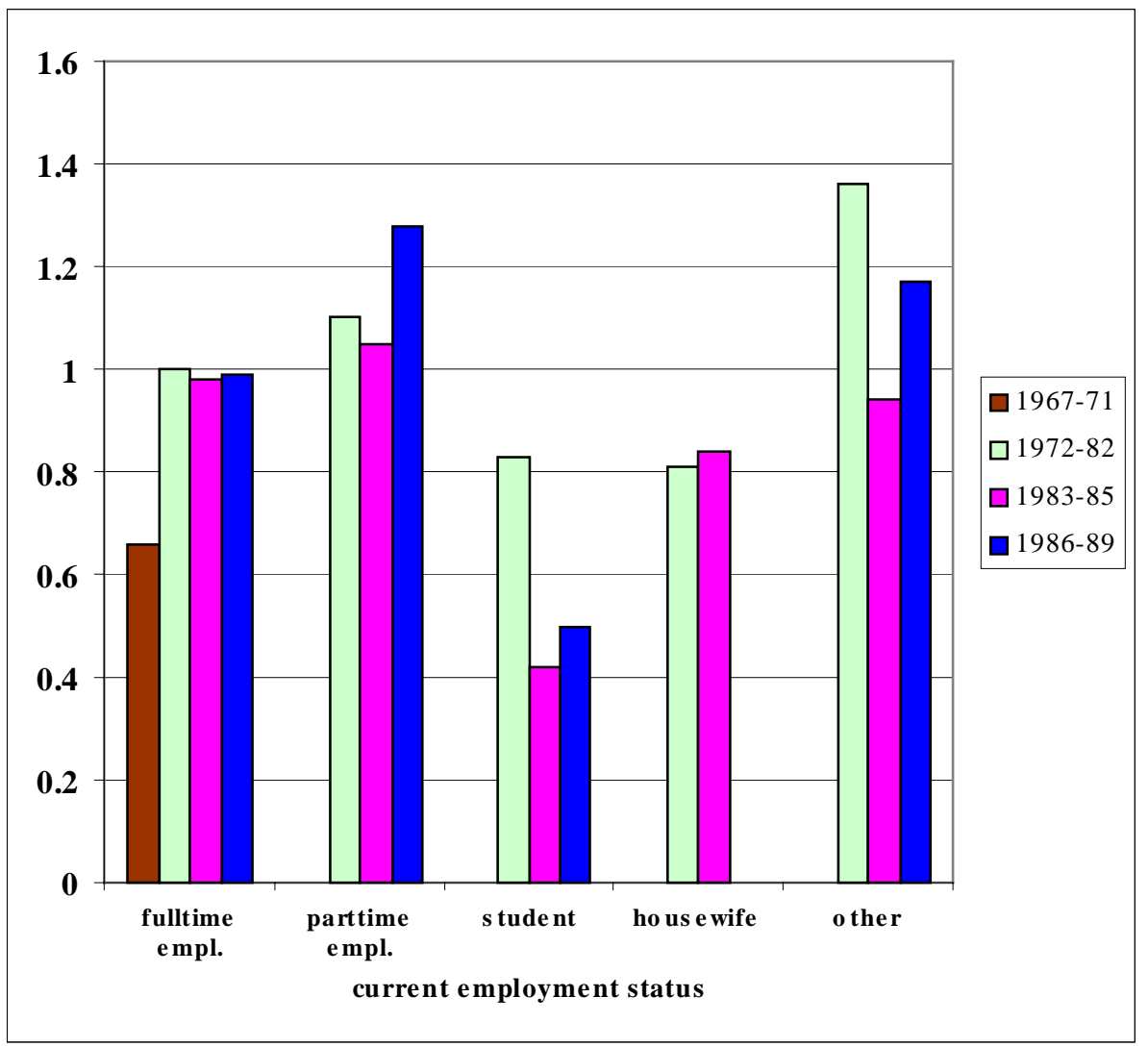

Figure 3: $\quad$ First-birth intensities in first co-residential union for Hungarian women, by current calendar period and current employment status*.

Standardized for the respondent's number of siblings, age at first union formation, type of first partnership, birth control at first sex, attitude to abortion, religiosity, current educational attainment, and duration of first union.

Note: $p=0.073$

* Cells with very little exposure time are not shown. 
weaker labor-force attachment (as in Poland). We suggest that it is not female employment per se, but rather the adequate policy support, which would greatly limit the opportunity cost of childbearing, (or the lack of such support) that matters for fertility decisions and behavior in the dual-earner context.

A further component of women's economic independence, higher education seems, however, to delay the transition to motherhood (see results for both countries). This may reflect the limited changes in family-level gender relations in the socialist period, as domestic tasks have remained women's duties besides their usual full-time employment, without much help from their men. In such circumstances, the more highly educated women more often postponed their first birth, enabling them to meet the demands of starting a career. This in turn also increased their risk to forego motherhood altogether.

Finally, we examined the role of a few attitude/value variables, but found, contrary to our expectation, that these factors remained relatively unimportant for the transition to motherhood. All in all, our findings suggest that gender relations influence family behavior. Various dimensions of gender equality at the societal level can indeed facilitate family formation with policies that, via institutional settings and services, support the combination of employment and family life. Yet, we argue that a more equal division of the domestic burden between women and men in the family is also important if women are to be able to become mothers, if and when they wish, notwithstanding their educational level and constraints of time and energy.

\section{Acknowledgements}

We thank Statistics Hungary and the Institute of Statistics and Demography, Warsaw School of Economics for providing access to their Family Surveys. We also thank the three anonymous reviewers for their constructive criticism. Financial support for this research for Livia Oláh from the Humanistic and Social Science Research Foundation (Grant F0931/1999) in Sweden, and for Ewa Fratczak from Research Project No.03/S/0059/02 "Destandardisation of the Life Course", Warsaw School of Economics - SGH, Poland, are gratefully acknowledged. 
Demographic Research - Special Collection 3: Article 9

-- Contemporary Research on European Fertility -- Perspectives and Developments --

\section{Notes}

1. The present paper is based on a previous project investigating first marriage formation and first childbearing in first marriages in Hungary and Poland from the mid-1960s to the early 1990s, published in the proceedings of the EPC 2003 (Oláh and Fratczak, 2003).

2. For a discussion on why the same theories can be used in studies of state-socialist Eastern Europe and the capitalist West when analyzing various features of a social context, see Gal and Kligman (2000: 7-10). They have also pointed out that the 'structural similarities' between state-socialist countries and Western welfare states 'are striking' (ibid: 63).

3. For an overview on the debate in the feminist literature on whether women's dependence on the state instead of individual men promotes women's independence, and on its relevance in the state-socialist context, see Gal and Kligman (2000: Chapter 4).

4. Although non-marital cohabitation as first partnership was quite rare in Poland even in the early 1990s, this was not the case in Hungary. Around 4 per cent of Polish women born in 1962-1966, but 18 per cent of Hungarian women born in 1963-67, had entered such union by age 24 . Voluntary LAT-relationships were even less common in these countries, given the severe housing shortage. At the same time, the share of non-marital births among all births was below 7 per cent in Poland, but twice as high in Hungary (Holzer and Kowalska, 1997; Kamarás, 1999).

5. Whereas in Hungary about 10-15 per cent of children below age three were enrolled in day nurseries in the 1970s and 1980s, their proportion remained around 4 per cent in Poland (see Statistical Yearbooks for Hungary and Poland, respectively), revealing a discrepancy between policy rhetoric and the level of provision.

6. There were 1933 and 4335 men interviewed for Hungary and Poland, respectively, but childbearing histories have been recorded only for women in Poland. Response rate among men was lower than among women, especially in Hungary (Holzer and Kowalska, 1997; Kamarás, 1999).

7. The start of the first union is based on the information given in the FFS, regarding the year and month when the couple moved together or got married, whichever event came first. We have not been able to control for whether a couple started their joint life while co-residing with the parents of the male or the female partner, 
as we have information only on whether the respondent was living in her parental home at first union start, but we do not know if the couple moved in with the partner's parents.

8. About one-fifth of the Polish female sample was born before 1950 (888 women), while none of the Hungarian sample was born before this time. There were 351 women excluded from the Hungarian sample, and 227 from the Polish sample, for entering their first union in December 1989 or later.

9. We have used information on newly built dwellings per thousand inhabitants, available in Statistical yearbooks, for Hungary and Poland, respectively, during the period of state socialism. 
Demographic Research - Special Collection 3: Article 9

-- Contemporary Research on European Fertility -- Perspectives and Developments --

\section{References}

Adamik, M., 1991. "Hungary - Supporting parenting and child rearing: Policy innovation in Eastern Europe." In: Kamerman S.B., and Kahn, A.J. (eds), Child Care, Parental Leave and the Under 3s: Policy Innovation in Europe. Auburn House, Paris: 115-144.

Ahrne, G., and Roman, C., 1997. "Hemmet, barnen och makten: Förhandlingar om arbete och pengar i familjen (Home, children and power: Bargaining around work and money in the family)." Statens Offentliga Utredningar 1997: 139. Ministry of Labor, Stockholm.

Andersson, G., 2000. "The impact of labour-force participation on childbearing behaviour: Pro-cyclical fertility in Sweden during the 1980s and 1990s." European Journal of Population 16 (4): 293-333.

Andorka, R., 1996. "Demographic changes and their main characteristics from 1960 to our days." In: Tóth, P.P., and Valkovics, E. (eds), Demography of Contemporary Hungarian Society. Atlantic Research and Publications, Highland Lakes: 21-36.

Balcerzak-Paradowska, B., 1998. "State policy towards the family." In: Golinowska, S. (ed.), Social Policy in the 1990s: Legal Regulations and Their Prospected Results. IPISS, Warszawa: 307-333.

Baxter, J., and Kane, E.W., 1995. "Dependence and independence: A cross-national analysis of gender inequality and gender attitudes." Gender \& Society 9 (2): 193-215.

Becker, G.S., 1981. A Treatise on the Family. Harvard University Press, Cambridge.

Bernhardt, E.M., 1993. "Fertility and employment." European Sociological Review 9 (1): 25-42.

Bloom, D.E., and Trussell, J., 1984. "What are the determinants of delayed childbearing and permanent childlessness in the United States?" Demography 21 (4): 591-611.

Blossfeld, H.-P., and Jaenichen, U., 1992. "Educational expansion and changes in women's entry into marriage and motherhood in the Federal Republic of Germany." Journal of Marriage and the Family 54 (2): 302-315.

Boleslawski, L., 1993. Polskie Ttablice Dzietnosci Kobiet 1972-1992. GUS, Warsaw. 
Castro Martín, T., 1992. "Delayed childbearing in contemporary Spain: Trends and differentials." European Journal of Population 8 (3): 275-294.

Council of Europe, different years. Recent Demographic Developments in Europe. Council of Europe Press, Strasbourg.

Etzler, C., 1987. "Första barnet: En demografisk studie av barnafödande bland svenska kvinnor födda 1936-60 (The first child. A demographic study of childbearing of Swedish women born 1936-60)." Stockholm Research Reports in Demography 44. Stockholm University, Stockholm.

Fratczak, E., Kowalska, I., Rohwer, G., Drobnic, S., and Blossfeld, H.-P., 1996. Polish Family and Fertility Survey: A User's Guide. School of Economics at the University of Bremen and Warsaw, Warsaw / Bremen.

Gal, S., and Kligman, G., 2000. The Politics of Gender After Socialism: A Comparative-Historical Essay. Princeton University Press, Princeton.

Hobson, B., 1990. "No exit, no voice: Women's economic dependency and the welfare state." Acta Sociologica 33 (3): 235-250.

Hoem, B., 1992. "Early phases of family formation in contemporary Sweden." In: Rosenheim, M., and Testa, M. (eds), Early Parenthood and Coming of Age in the 1990s. Rutgers University Press, New Brunswick: 183-199.

Hoem, B., 2000. "Entry into motherhood in Sweden: The influence of economic factors on the rise and fall in fertility, 1986-1997." Demographic Research 2 (4). Available http://www.demographic-research.org/volumes/vol2/4/

Hoem, J.M., 1993. "Public policy as the fuel of fertility: Effects of a policy reform on the pace of childbearing in Sweden in the 1980s." Acta Sociologica 36 (1): 1931.

Holzer, J.Z., 1991. "Poland.“ In: Rallu, J.-L., and Blum, A. (eds), European Population I. Country Analysis. John Libbey, Paris: 177-190.

Holzer, J.Z., and Kowalska, I., 1997. Fertility and Family Surveys in Countries of the ECE Region. Standard Country Report - Poland. United Nations, New York/Geneva.

Joshi, H., 1998. "The opportunity costs of childbearing: More than mothers' business." Journal of Population Economics 11 (2): 161-183.

Kamarás, F., 1999. Fertility and Family Surveys in Countries of the ECE Region. Standard Country Report: Hungary. United Nations, New York/Geneva. 
Klinger, A., 1991. "Hungary." In: Rallu, J.-L., and Blum, A. (eds), European Population I. Country Analysis. John Libbey, Paris: 209-223.

Kravdal, Ø., 1994. "The importance of economic activity, economic potential and economic resources for the timing of first births in Norway." Population Studies 48 (2): 249-267.

Kuciarska-Ciesielska, M., 1993. "Birth control and its determinants." Polish Population Review 3: 221-240.

Lesthaeghe, R., 1983. "A century of demographic and cultural change in Western Europe: An exploration of underlying dimensions." Population and Development Review 9 (3): 411-435.

Liefbroer, A.C., and Fratczak E., 1996. "The family formation process in Poland during the early years of the socio-economic transition: Evidence from the Polish family and fertility survey 1991." Studia Demograficzne 123-124 (1-2): $39-55$.

Makkai, T., 1994. "Social policy and gender in Eastern Europe." In: Sainsbury, D. (ed.), Gendering Welfare States. Sage, London: 188-205.

Marody, M., and Giza-Poleszczuk, A., 2000. "Changing images of identity in Poland: From the self-sacrificing to the self-investing women?" In: Gal, S., and Kligman, G. (eds), Reproducing Gender: Politics, Publics, and Everyday Life After Socialism. Princeton University Press, Princeton: 151-175.

Menken, J.L., 1985. “Age and fertility: How late can you wait?" Demography 22 (4): 469-483.

Oláh, L.Sz., 2001. Gendering Family Dynamics: The Case of Sweden and Hungary. Ph.D. thesis. Demography Unit at the Stockholm University, Stockholm.

Oláh, L.Sz., Bernhardt, E.M., and Goldscheider, F.K., 2002. "Coresidential paternal roles in industrialized countries: Sweden, Hungary and the United States." In: Hobson, B. (ed.), Making Men Into Fathers: Men, Masculinities and the Social Politics of Fatherhood. Cambridge University Press, Cambridge: 25-57.

Oláh, L.Sz., and Fratczak, E., 2003. "Gendering family formation. First marriage and first birth in Hungary and Poland." In: Kotowska, I.E., and Józwiak, J. (eds), Population of Central and Eastern Europe. Challenges and Opportunities. Statistical Publishing Establishment, Warsawa: 219-249.

Oppenheimer, V.K., 1994. "Women's rising employment and the future of the family in industrial societies." Population and Development Review 20 (3): 293-342. 
Radványi, M.K., 1992. "The politics of economic reform in Eastern Europe." In: Taras, R.C. (ed.), Handbook of Political Science Research on the USSR and Eastern Europe: Trends from the 1950s to the 1990s. Greenwood Press, Westport: 286-301.

Ratajczak, B., 1993. "The housing situation of families in Poland in the light of the national census 1988 results." Polish Population Review 3: 241-253.

Rindfuss, R.R., and St. John, C., 1983. "Social determinants of age at first birth." Journal of Marriage and the Family 45 (3): 553-565.

Rindfuss, R.R., Philip, M.S., and Swicegood, G., 1988. First Birth in America: Changes in the Timing of Parenthood. University of California Press, Berkeley.

Rindfuss, R.R., Philip, M.S., and Offutt, K., 1996. "Education and the changing age pattern of American fertility: 1963-1989." Demography 33 (3): 277-290.

Sándorné Horváth, E., 1986. A GYEStöl a GYEDig (From Child-Care Allowance To Child-Care Pay). Kossuth, Budapest.

Santow, G., and Bracher, M., 2001. "Deferment of the first birth and fluctuating fertility in Sweden." European Journal of Population 17 (4): 343-363.

Tárkányi, Á., 2001/2002. "A családdal kapcsolatos jogszabályok Magyarországon 1980-98-ig (Legal rules regarding family issues in Hungary, 1980-98).” KSH NKI Kutatási Jelentések 67 (Statistics Hungary Demographic Research Inst. Research Reports 67), KSH NKI, Budapest.

Thomson, E., and Hoem, J.M., 1998. "Couple childbearing plans and births in Sweden.” Demography 35 (3): 315-322.

Thomson, E., Hoem, J.M., Vikat, A., Prskawetz, A., Buber, I., Toulemon, L., Henz, U., Godecker, A.L., and Kantorová, V., 2002. "Childbearing in stepfamilies: How parity matters." In: Klijzing, E., and Corijn, M. (eds), Dynamics of Fertility and Partnership in Europe. Insights and Lessons From Comparative Research. Volume II. United Nations, New York/Geneva: 87-99.

van de Kaa, D.J., 1994. "The second demographic transition revisited: Theories and expectations.” In: Beets, G.C.N., van den Brekel, J.C., Cliquet, R.L., Dooghe, G., and de Jong Gierveld, J. (eds), Population and Family in the Low Countries 1993: Late Fertility and Other Current Issues. Swets \& Zeitlinger, Amsterdam: 81-126.

Watson, P., 1993. "Eastern Europe's silent revolution: Gender." Sociology 27 (3): 471-487. 
Demographic Research - Special Collection 3: Article 9

-- Contemporary Research on European Fertility -- Perspectives and Developments --

Wu, Z., and MacNeill, L., 2002. "Education, work and childbearing after age 30." Journal of Comparative Family Studies 33 (2): 191-213. 
Demographic Research - Special Collection 3: Article 9

-- Contemporary Research on European Fertility -- Perspectives and Developments --

\section{APPENDIX}

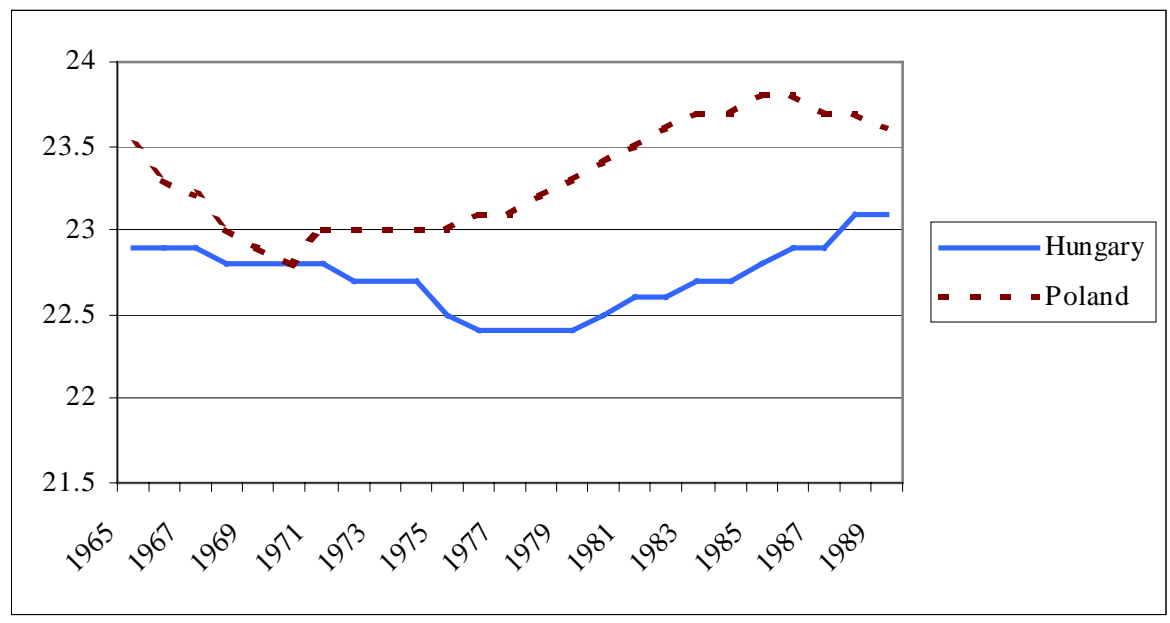

Figure A: $\quad$ Mean age at first birth in Hungary and Poland, 1965-1989

Source: Council of Europe (different years) 
Demographic Research - Special Collection 3: Article 9

-- Contemporary Research on European Fertility -- Perspectives and Developments --

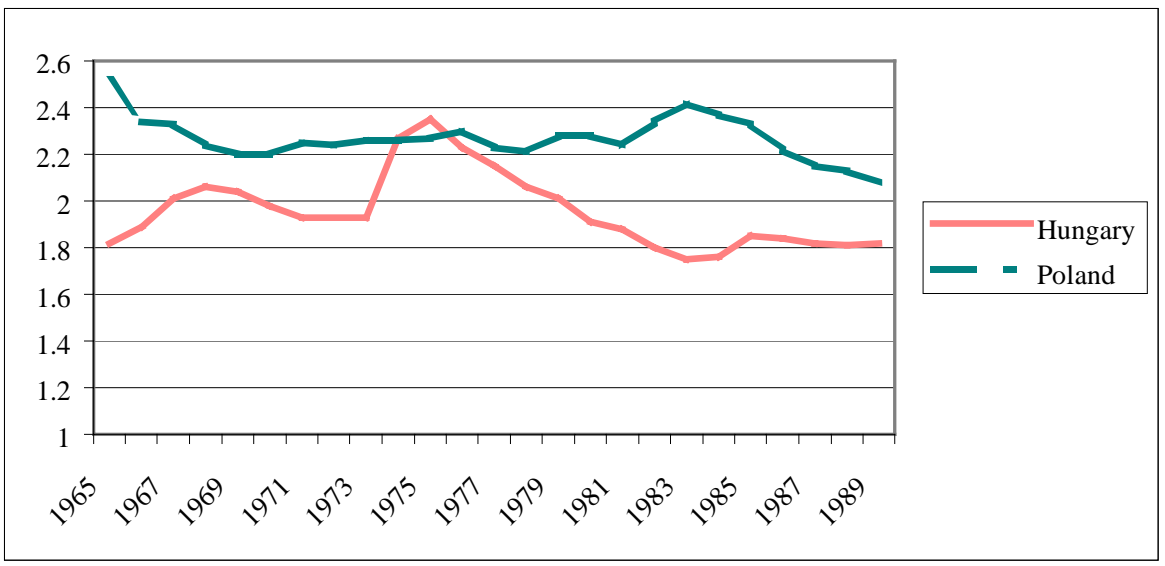

Figure B: $\quad$ Total Fertility Rate, Hungary and Poland, 1965-1989

Source: Council of Europe (different years)

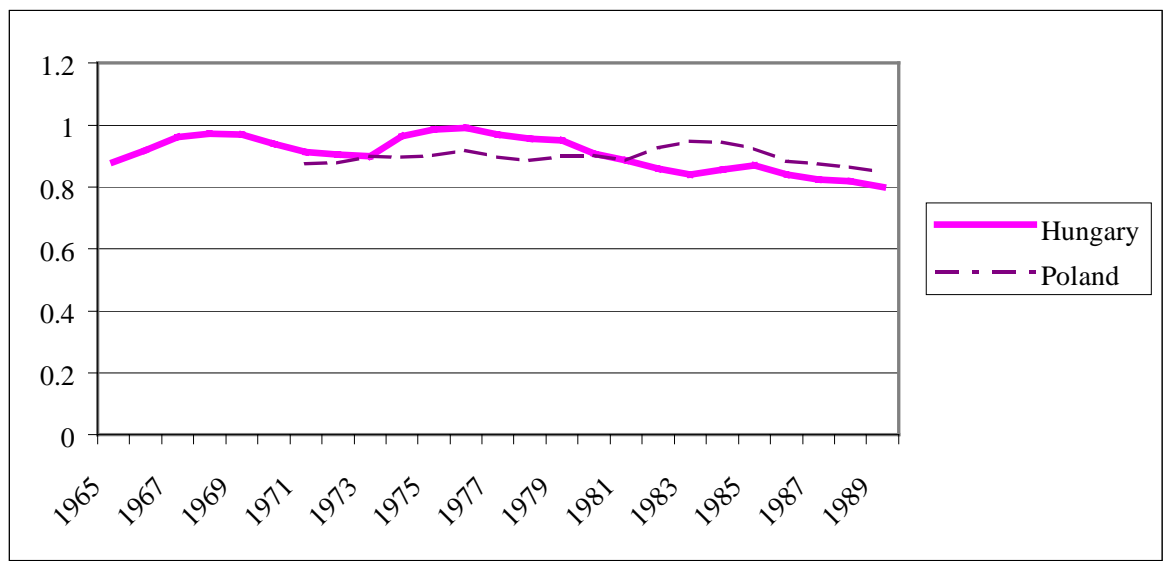

Figure C: $\quad$ Total First-Birth Rate*, Hungary and Poland, 1965-1989

* period TFR1

Source: Statistics Hungary; Dimiter Philipov (own calculations); Boleslawski (1993) 
Demographic Research - Special Collection 3: Article 9

-- Contemporary Research on European Fertility -- Perspectives and Developments --

Table A: Distributions of respondents (or exposure time as childless) at the various levels of covariates applied in the models. Childless women in first co-residential union.

\begin{tabular}{|c|c|c|c|c|}
\hline & \multicolumn{2}{|l|}{ Hungary } & \multicolumn{2}{|l|}{ Poland } \\
\hline & Number of respondents & Per cent & Number of respondents & Per cent \\
\hline \multicolumn{5}{|l|}{ FIXED COVARIATES: } \\
\hline \multicolumn{5}{|l|}{ cohort: } \\
\hline $1950-1954$ & 540 & 22.3 & 674 & 32.2 \\
\hline $1955-1959$ & 765 & 31.6 & 614 & 29.4 \\
\hline $1960-1964$ & 595 & 24.6 & 501 & 24.0 \\
\hline $1965-1969$ & 449 & 18.5 & 269 & 12.9 \\
\hline $1970-1973$ & 73 & 3.0 & 32 & 1.5 \\
\hline \multicolumn{5}{|l|}{ religiosity (activity level): } \\
\hline Active & 343 & 14.2 & 1766 & 84.5 \\
\hline not active & 2079 & 85.8 & 324 & 15.5 \\
\hline \multicolumn{5}{|l|}{ number of siblings: } \\
\hline no sibling & 346 & 14.3 & 5 & 0.2 \\
\hline one sibling & 1027 & 42.4 & 110 & 5.3 \\
\hline two siblings & 506 & 20.9 & 559 & 26.7 \\
\hline three or more siblings & 543 & 22.4 & 1416 & 67.8 \\
\hline \multicolumn{5}{|l|}{ childhood family: } \\
\hline intact family & 2006 & 82.8 & 1873 & 89.6 \\
\hline parents divorced & 262 & 10.8 & 55 & 2.6 \\
\hline other non-intact family & 154 & 6.4 & 162 & 7.8 \\
\hline \multicolumn{5}{|l|}{ age at first union formation: } \\
\hline below 18 years & 400 & 16.5 & 96 & 4.6 \\
\hline 18 years & 423 & 17.5 & 220 & 10.5 \\
\hline 19 years & 433 & 17.9 & 309 & 14.7 \\
\hline 20 years & 369 & 15.2 & 321 & 15.4 \\
\hline 21 years & 257 & 10.6 & 327 & 15.7 \\
\hline 22 years & 195 & 8.0 & 244 & 11.7 \\
\hline 23 years & 122 & 5.0 & 189 & 9.0 \\
\hline 24 years & 77 & 3.2 & 137 & 6.6 \\
\hline 25 years & 53 & 2.2 & 88 & 4.2 \\
\hline $26-28$ years & 65 & 2.7 & 123 & 5.9 \\
\hline 29-31 years & 23 & 1.0 & 24 & 1.1 \\
\hline $32+$ years & 5 & 0.2 & 12 & 0.6 \\
\hline \multicolumn{5}{|l|}{ type of first partnership: } \\
\hline direct marriage & 2073 & 85.6 & 2011 & 96.2 \\
\hline union begun as cohabitation & 349 & 14.4 & 79 & 3.8 \\
\hline
\end{tabular}


Demographic Research - Special Collection 3: Article 9

-- Contemporary Research on European Fertility -- Perspectives and Developments --

\section{Table A: (Cont.)}

\begin{tabular}{|c|c|c|c|c|}
\hline \multicolumn{5}{|l|}{ birth control at first sex: } \\
\hline non-use (incl. no information) & 1272 & 52.5 & 1153 & 55.2 \\
\hline Withdrawal & 194 & 8.0 & 673 & 32.2 \\
\hline Rhythm & 48 & 2.0 & 205 & 9.8 \\
\hline Condom & 152 & 6.3 & 10 & 0.5 \\
\hline chemical measures & 16 & 0.7 & 15 & 0.7 \\
\hline IUD (P: incl. pill) & 11 & 0.4 & 34 & 1.6 \\
\hline Pill & 729 & 30.1 & & \\
\hline \multicolumn{5}{|l|}{ attitude to abortion: } \\
\hline Restrictive & 284 & 11.7 & 700 & 33.5 \\
\hline allowing for unmarried & 259 & 10.7 & 27 & 1.3 \\
\hline Liberal & 1196 & 49.4 & 1262 & 60.4 \\
\hline Other & 683 & 28.2 & 101 & 4.8 \\
\hline Total: & 2422 & 100.0 & 2090 & 100.0 \\
\hline \multicolumn{5}{|c|}{$\begin{array}{l}\text { TIME-VARYING COVARIATES: } \\
\text { current calendar period: }\end{array}$} \\
\hline $\mathrm{H}:$ 1967-71; P: 1967-72 & 2568 & 2.4 & 5302 & 7.5 \\
\hline H: 1972-82; P: 1973-81 & 58450 & 54.1 & 34326 & 48.6 \\
\hline H: 1983-85; P: $1982-89$ & 19903 & 18.4 & 31034 & 43.9 \\
\hline H: 1986-89 & 27077 & 25.1 & & \\
\hline \multicolumn{5}{|l|}{ current educational attainment: } \\
\hline primary school & 32116 & 29.7 & 8544 & 12.1 \\
\hline lower-secondary school & 21782 & 20.2 & 22812 & 32.3 \\
\hline upper-secondary school & 42704 & 39.5 & 32786 & 46.4 \\
\hline tertiary education & 11396 & 10.6 & 6520 & 9.2 \\
\hline \multicolumn{5}{|l|}{ current employment status: } \\
\hline full-time employed & 90300 & 83.6 & 57630 & 81.5 \\
\hline part-time employed (long and & 4692 & 4.3 & 676 & 1.0 \\
\hline Unemployed & 226 & 0.2 & 268 & 0.4 \\
\hline Student & 5912 & 5.5 & 4434 & 6.3 \\
\hline Housewife & 1904 & 1.8 & 1632 & 2.3 \\
\hline other non-employed & 4964 & 4.6 & 6022 & 8.5 \\
\hline $\begin{array}{l}\text { duration of first union in } \\
\text { months (time factor): } \\
1-7 \text { months }\end{array}$ & 35788 & 33.1 & 28810 & 40.8 \\
\hline $8-18$ months & 29086 & 26.9 & 18186 & 25.8 \\
\hline $19-24$ months & 9476 & 8.8 & 4618 & 6.6 \\
\hline $25-36$ months & 12236 & 11.3 & 5802 & 8.2 \\
\hline $37-48$ months & 6890 & 6.4 & 3352 & 4.7 \\
\hline $49-60$ months & 4372 & 4.1 & 2274 & 3.2 \\
\hline $61-120$ months & 7866 & 7.3 & 5260 & 7.4 \\
\hline $121+$ months & 2284 & 2.1 & 2360 & 3.3 \\
\hline Total exposure time & 107998 & 100.0 & 70662 & 100.0 \\
\hline
\end{tabular}


Demographic Research - Special Collection 3: Article 9

-- Contemporary Research on European Fertility -- Perspectives and Developments -- 